\title{
On Infinitesimal Approximation of a Continuous Function
}

Tahir H. Ismail

tahir_hsis@uomosul.edu.iq

College of Computer Sciences and Mathematics

University of Mosul

Received on: 2/9/2009

Accepted on: 11/4/2010

\section{ABSTRACT}

If $\mathrm{P}$ and $\mathrm{Q}$ are convex subsets in $\mathrm{C}(\mathrm{X})$, and $\mathrm{q}(\mathrm{x})>0$ in $\mathrm{X}$ for all $\mathrm{q} \in \mathrm{Q}$. If the approximation family is the set

$$
\mathrm{T}=\{\mathrm{p} / \mathrm{q}: \mathrm{p} \in \mathrm{P}, \mathrm{q} \in \mathrm{Q}\}
$$

An Infinitesimal approximation of $f \in C(X)$ an element in $T$ established in [4],[5]. A characterization of an infinitesimal approximation, necessary and sufficient conditions for the unique infinitesimal approximation are obtained.

Keywords: infinitesimal, approximation, continuous function, convex set.

$$
\begin{aligned}
& \text { حول تقريب متناهي الصغر للالة المستمرة } \\
& \text { طاهر حسن إسماعيل } \\
& \text { كلية علوم الحاسوب والرياضيات، جامعة الموصل }
\end{aligned}
$$

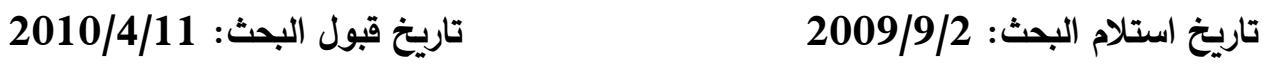

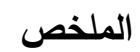

$$
\begin{aligned}
& \text { الهدف من هذا البحث هو دراسة تقريب متتاهي الصغر لدالة f } \\
& \text { بعض طرق التحليل غير القياسي الذي أوجده Robinson A ووضعه .Nelson E بأسلوب } \\
& \text { منطقي وأكثر دقة. }
\end{aligned}
$$

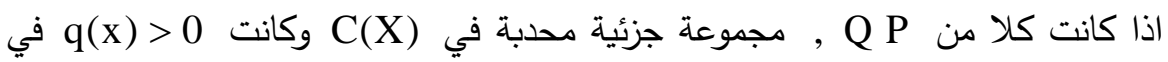

$$
\begin{aligned}
& \text { لكل q, وكانت العائلة المقربة هي المجموعة } \\
& \mathrm{T}=\{\mathrm{p} / \mathrm{q}: \mathrm{p} \in \mathrm{P}, \mathrm{q} \in \mathrm{Q}\} \\
& \text { تم تعيين عنصر في T لتقريب متتاهي الصغر لدالة feC(X) وتم الحصول على } \\
& \text { الشرط الضروري والكافي لوحدانية التقريب متتاهي الصغر . } \\
& \text { الكلمات المفتاحية: ما لانهاية من الصغر ، تقريب، دالة مستمرة، مجموعة محدبة. }
\end{aligned}
$$

\section{1- Introduction:}

In this paper the problem of obtaining an infinitesimal approximation with a necessary and sufficient conditions for the uniqueness of infinitesimal approximation are considered and studied. 
The following definitions and statements of nonstandard analysis will be needed throughout this papers [3],[4],[6].

The axioms of IST given by Nelson E. [3] are the axioms of ZFC together with three additional axioms, which are called the transfer principle (T), the idealization principle (I), and the standardization principle (S) are stated by the following:

\section{Transfer principle $(\mathrm{T})$}

Let $A\left(x, t_{1}, t_{2}, \ldots, t_{n}\right)$ be an internal formula with free variables $\mathrm{x}, \mathrm{t}_{1}, \mathrm{t}_{2}, \ldots, \mathrm{t}_{\mathrm{n}}$ only, then

$\forall^{\text {st }} \mathrm{t}_{1}, \mathrm{t}_{2}, \ldots, \forall^{\mathrm{st}} \mathrm{t}_{\mathrm{n}} \quad\left(\forall^{\mathrm{st}} \mathrm{xA}\left(\mathrm{x}, \mathrm{t}_{1}, \mathrm{t}_{2}, \ldots, \mathrm{t}_{\mathrm{n}}\right)\right) \Leftrightarrow \forall \mathrm{x}\left(\mathrm{x}, \mathrm{t}_{1}, \mathrm{t}_{2}, \ldots, \mathrm{t}_{\mathrm{n}}\right)$

\section{Idealization principle (I)}

Let $\mathrm{B}(\mathrm{x}, \mathrm{y})$ be an internal formula with free variables $\mathrm{x}, \mathrm{y}$ and with possibly other free variables. Then

$$
\forall^{\text {st Fin }} \mathrm{z} \exists \mathrm{x} \forall \mathrm{y} \in \mathrm{Z} \wedge \mathrm{B}(\mathrm{x}, \mathrm{y}) \Leftrightarrow \exists \mathrm{x} \forall^{\mathrm{st}} \mathrm{yB}(\mathrm{x}, \mathrm{y})
$$

\section{Standardization principle (S)}

Let $\mathrm{C}(\mathrm{Z})$ be a formula, internal or external with free variable $\mathrm{z}$ and with possibly other free variables. Then

$$
\forall^{\text {st }} \mathrm{x} \exists^{\text {st }} \mathrm{y} \forall^{\text {sd }} \mathrm{z}(\mathrm{z} \in \mathrm{Y}) \Leftrightarrow \mathrm{z} \in \mathrm{X} \wedge \mathrm{C}(\mathrm{Z})
$$
standard.

Every set or element defined in a classical mathematics is called

Any set or formula which does not involve new predicates "standard, infinitesimal, limited, unlimited, ...etc." is called internal, otherwise is called external.

A real number $\mathrm{x}$ is called unlimited if $|\mathrm{x}|>\mathrm{r}$ for all positive standard real number $\mathrm{r}$, otherwise it is called limited.

The set of all unlimited real numbers is denoted by $\overline{\mathrm{IR}}$, and the set of all limited real numbers is denoted by $\underline{\mathbb{R}}$.

A real number is called infinitesimal if $|\mathrm{x}|<\mathrm{r}$ for all positive standard real number $\mathrm{r}$.

A real number $\mathrm{x}$ is called appreciable if it is neither unlimited nor infinitesimal, and the set of all positive appreciable numbers is denoted by $\mathrm{A}^{+}$.

Two real numbers $\mathrm{x}$ and $\mathrm{y}$ are said to be infinitely close if $\mathrm{x}-\mathrm{y}$ is infinitesimal and denoted by $\mathrm{x} \cong \mathrm{y}$. 
If $x$ is a limited number in IR, then it is infinitely close to a unique standard real number, this unique number is called the standard part of $\mathrm{x}$ or the shadow of $\mathrm{x}$, denoted by ${ }^{\circ} \mathrm{x}$.

If $\mathrm{f}$ is a real valued function, then $\mathrm{f}$ is called continuous at $\mathrm{x}_{0}$ where $\mathrm{f}$ and $\mathrm{x}_{0}$ are standard and $\mathrm{x} \cong \mathrm{x}_{0}=\mathrm{f}\left(\mathrm{x}_{0}\right) \cong \mathrm{f}(\mathrm{x})$ for all $\mathrm{x} \in \mathrm{X}$.

Let $X$ be a compact metric space and $C(X)$ be the space of continuous real valued functions $\mathrm{f}$ defined on $\mathrm{X}$ with norm defined by

$$
\|f\|=\sup _{x \in X}|f(x)|
$$

If $\mathrm{P}$ and $\mathrm{Q}$ are convex subsets in $\mathrm{C}(\mathrm{X})$ and $\mathrm{q}(\mathrm{x})>0$ in $\mathrm{X}$ for all $\mathrm{q} \in \mathrm{Q}$. The approximation family is the set

$$
\mathrm{T}=\{\mathrm{p} / \mathrm{q}: \mathrm{p} \in \mathrm{P}, \mathrm{q} \in \mathrm{Q}\}
$$

The problem is given by an element $\mathrm{f} \in \mathrm{C}(\mathrm{X})$, Find $\mathrm{t}_{0} \in \mathrm{T}$ such that

$$
\left\|\mathrm{f}-\mathrm{t}_{0}\right\| \cong \inf _{\mathrm{t} \in \mathrm{T}}|\mathrm{f}-\mathrm{t}|
$$

Where $t_{0}$ is the infinitesimal approximation of $f$ in $T$. The present paper deals with the study of the unique infinitesimal approximation, by using some concepts of nonstandard analysis, for details (see [1],[2],[3]).

\section{Main Results:}

Proposition(1): Let $X_{t}=\{x \in X:\|f(x)-t(x)\| \cong|f-t|\}$. Then for any

$$
\begin{aligned}
& \mathrm{t}_{1}, \mathrm{t}_{2} \in \mathrm{T}, \| \mathrm{f}-\mathrm{t}_{1}|<\cong| \mathrm{f}-\mathrm{t}_{2} \mid \text { implies that } \\
& \sup _{\mathrm{x} \in \mathrm{X}_{\mathrm{t}}}\left\{\left(\mathrm{t}_{2}(\mathrm{x})-\mathrm{t}_{1}(\mathrm{x})\right)\left(\mathrm{f}(\mathrm{x})-\mathrm{t}_{2}(\mathrm{x})\right)\right\}<\cong 0
\end{aligned}
$$

Proof: Since $\| f-t_{1}||<\cong\left|f-t_{2}\right|$ implies that

$$
\left\{\left(\mathrm{f}(\mathrm{x})-\mathrm{t}_{2}(\mathrm{x})\right)\left(\mathrm{f}(\mathrm{x})-\mathrm{t}_{1}(\mathrm{x})\right)\right\}\left(\mathrm{f}(\mathrm{x})-\mathrm{t}_{1}(\mathrm{x})\right)>\cong 0 \text { for all } \mathrm{x} \in \mathrm{X}_{\mathrm{t}_{2}}
$$

That is $\| \mathrm{f}-\mathrm{t}_{1}||<\cong\left|\mathrm{f}-\mathrm{t}_{2}\right|$ implies that

$$
\left(\mathrm{t}_{2}(\mathrm{x})-\mathrm{t}_{1}(\mathrm{x})\right)\left(\mathrm{f}(\mathrm{x})-\mathrm{t}_{2}(\mathrm{x})\right)<\cong 0, \forall \mathrm{x} \in \mathrm{X}_{\mathrm{t}_{2}}
$$

Thus $\| \mathrm{f}-\mathrm{t}_{1}||<\cong\left|\mathrm{f}-\mathrm{t}_{2}\right|$ implies that $\sup _{\mathrm{x} \in \mathrm{X}_{\mathrm{t}_{2}}}\left\{\left(\mathrm{t}_{2}(\mathrm{x})-\mathrm{t}_{1}(\mathrm{x})\right)\left(\mathrm{f}(\mathrm{x})-\mathrm{t}_{2}(\mathrm{x})\right)\right\}<\cong 0$

Hence the proof.

Proposition(2): Let $\mathrm{P}$ and $\mathrm{Q}$ be convex sets in $\mathrm{C}(\mathrm{X})$.Then, an element $\mathrm{t}_{0} \in \mathrm{T}$ is an infinitesimal approximation of $\mathrm{f} \in \mathrm{C}(\mathrm{X})$ in $\mathrm{T}$ if and only if

$$
\sup _{\mathrm{x} \in \mathrm{X}_{\mathrm{t}_{2}}}\left\{\left(\mathrm{t}_{0}(\mathrm{x})-\mathrm{t}(\mathrm{x})\right)\left(\mathrm{f}(\mathrm{x})-\mathrm{t}_{0}(\mathrm{x})\right)\right\}>\cong 0 \text { for all } \mathrm{x} \in \mathrm{X}_{\mathrm{t}_{2}}
$$


Proof: Let $\mathrm{t} \in \mathrm{T}$ be such that

$$
\|\mathrm{f}-\mathrm{t}\|<\cong\left|\mathrm{f}-\mathrm{t}_{0}\right|
$$

By proposition (1) we have

$$
\sup _{\mathrm{x} \in \mathrm{X}_{\mathrm{t}}}\left\{\left(\mathrm{t}_{0}(\mathrm{x})-\mathrm{t}(\mathrm{x})\right)\left(\mathrm{f}(\mathrm{x})-\mathrm{t}_{0}(\mathrm{x})\right)\right\}<\cong 0
$$

Contradiction.

Conversely suppose that there is an element $t \in T$ satisfying (2).

Let $\mathrm{t}_{0}=\mathrm{p}_{0} / \mathrm{q}_{0}$ and $\mathrm{t}=\mathrm{p} / \mathrm{q}$, where $\mathrm{p}_{0}, \mathrm{p} \in \mathrm{P}$ and $\mathrm{q}_{0}, \mathrm{q} \in \mathrm{Q}$

But $\mathrm{t}_{\mathrm{r}}=(1-\mathrm{r}) \mathrm{p}_{0}+\mathrm{t}_{\mathrm{p}} /(1-\mathrm{r}) \mathrm{q}_{0}+\mathrm{t}_{\mathrm{q}}$

Let $\mathrm{y} \in \mathrm{X}_{\mathrm{t}_{0}}$, from (2) it follows that

$$
\begin{aligned}
\left|\mathrm{f}(\mathrm{x})-\mathrm{t}_{1}(\mathrm{x})\right| & =\left|\left(\mathrm{f}(\mathrm{x})-\mathrm{t}_{0}(\mathrm{x})\right)+\left(\mathrm{t}_{0}(\mathrm{x})-\mathrm{t}_{1}(\mathrm{x})\right)\right| \\
& =\left|\left(\mathrm{f}(\mathrm{x})-\mathrm{t}_{0}(\mathrm{x})\right)+\mathrm{tq}(\mathrm{x}) /(1-\mathrm{r}) \mathrm{q}_{0}(\mathrm{x})+\mathrm{rq}(\mathrm{x})\left(\mathrm{t}_{0}(\mathrm{x})-\mathrm{t}_{1}(\mathrm{x})\right)\right| \\
& =\left|\left(\mathrm{f}(\mathrm{x})-\mathrm{t}_{0}(\mathrm{x})\right)+\mathrm{tq}(\mathrm{x}) /(1-\mathrm{r}) \mathrm{q}_{0}(\mathrm{x})+\mathrm{rq}(\mathrm{x})\left(\mathrm{t}_{0}(\mathrm{x})-\mathrm{t}_{1}(\mathrm{x})\right)\right|
\end{aligned}
$$

If $r>0$ and $|x-y|$ are both infinitesimal. Then there exists a real $\mathrm{r}_{\mathrm{y}} \in[0,1]$ and a monad $\mathrm{M}_{\mathrm{y}}$ of the point $\mathrm{y} \in \mathrm{X}$ such that

$\left|\mathrm{f}(\mathrm{x})-\mathrm{t}_{1}(\mathrm{x})\right|<\varepsilon$, for all $\mathrm{x} \in\left(0, \mathrm{r}_{\mathrm{y}}\right], \forall \mathrm{x} \in \mathrm{M}_{\mathrm{y}}$

If $\mathrm{y} \in \mathrm{X}-\mathrm{X}_{\mathrm{t}_{0}}$ we have $\left|\mathrm{f}(\mathrm{y})-\mathrm{t}_{0}(\mathrm{y})\right|<\varepsilon$

Thus there exists $r_{y}>0$ and a monad $M_{y}$ of $y$ such that (3) holds, since the shadow

$$
{ }^{\mathrm{o}} \mathrm{t}_{0}=\mathrm{t}_{0},{ }^{\mathrm{o}} \mathrm{r}=0
$$

We can choose a finite subcover $\mathrm{M}_{\mathrm{y}_{1}}, \mathrm{M}_{\mathrm{y}_{2}}, \ldots, \mathrm{M}_{\mathrm{y}_{\mathrm{n}}}$ from the open covering $\left\{\mathrm{M}_{\mathrm{y}}\right\}$ of the compact metric space $\mathrm{X}$.

By taking the minimum of the corresponding positive numbers $r_{y_{1}}, r_{y_{2}}, \ldots, r_{y_{n}}$, denote it by $r$. We have $t \in(0,1]$ and

$$
\left|f(x)-t_{r}(x)\right|<\varepsilon, \text { for all } x \in X
$$

Hence $\left|\mathrm{f}-\mathrm{t}_{\mathrm{r}}\right|<\varepsilon$

Which is a contradiction, since

$$
\mathrm{t}_{\mathrm{r}}=\frac{(1-\mathrm{r}) \mathrm{p}_{0}-\mathrm{tp}_{0}}{(1-\mathrm{r}) \mathrm{q}_{0}-\mathrm{tq}_{0}} \in \mathrm{T}
$$

Proposition(3): Under the hypothesis of the proposition (2), if $\mathrm{f} \in \mathrm{C}(\mathrm{X})$ has an approximation in $\mathrm{T}$, then $\mathrm{t}_{0} \in \mathrm{T}$ is an infinitesimal approximation of $\mathrm{f}$ in $\mathrm{T}$ iff 
$\max _{x \in X_{t}}\left\{\left(t(x)-t_{0}(x)\right)(f(x)-t(x))\right\} \leq \max _{x \in X_{t}}\left\{\left(t_{0}(x)-t(x)\right)\left(f(x)-t_{0}(x)\right)\right\}$

for all $\mathrm{t} \in \mathrm{T}$

Proof: Let $\mathrm{t}_{0}$ be an infinitesimal approximation of $\mathrm{f}$ in $\mathrm{T}$

Thus $\left\|\mathrm{f}-\mathrm{t}_{0}\right\|<\cong|\mathrm{f}-\mathrm{t}|$ for all $\mathrm{t} \in \mathrm{T}$

It follows from proposition (1) that

$$
\max _{\mathrm{x} \in \mathrm{X}_{\mathrm{t}}}\left\{\left(\mathrm{t}(\mathrm{x})-\mathrm{t}_{0}(\mathrm{x})\right)(\mathrm{f}(\mathrm{x})-\mathrm{t}(\mathrm{x}))\right\} \leq 0 \text { for all } \mathrm{t} \in \mathrm{T}
$$

From (1) and the above relation we get

$\max _{x \in X_{t}}\left\{\left(t(x)-t_{0}(x)\right)(f(x)-t(x))\right\} \leq \max _{x \in X_{t}}\left\{\left(t_{0}(x)-t(x)\right)\left(f(x)-t_{0}(x)\right)\right\}$ for all $\mathrm{t} \in \mathrm{T}$

Conversely, suppose that (4) satisfied. If $\mathrm{t}_{0}$ is not an infinitesimal approximation of $\mathrm{f}$ in $\mathrm{T}$, while $\mathrm{t} \in \mathrm{T}-\left\{\mathrm{t}_{0}\right\}$ is an infinitesimal approximation of $\mathrm{f}$, by proposition (2), we have

$$
\max _{\mathrm{x} \in \mathrm{X}_{\mathrm{t}}}\left\{\left(\mathrm{t}(\mathrm{x})-\mathrm{t}_{0}(\mathrm{x})\right)(\mathrm{f}(\mathrm{x})-\mathrm{t}(\mathrm{x}))\right\} \geq 0 \quad \forall \mathrm{t}_{0} \in \mathrm{T}-\left\{\mathrm{t}_{0}\right\}
$$

From proposition (1), we have

$$
\max _{\mathrm{x} \in \mathrm{X}_{\mathrm{t}}}\left\{\left(\mathrm{t}(\mathrm{x})-\mathrm{t}_{0}(\mathrm{x})\right)(\mathrm{f}(\mathrm{x})-\mathrm{t}(\mathrm{x}))\right\} \leq 0
$$

Which contradicts (5).

Proposition(4): Under the hypothesis of proposition (3) the following statements are equivalent
(a) $\left\|\mathrm{f}-\mathrm{t}_{0}\right\|<|\mathrm{f}-\mathrm{t}| \quad \forall \mathrm{t} \in \mathrm{T}-\left\{\mathrm{t}_{0}\right\}$
(b) $\max _{\mathrm{x} \in \mathrm{X}_{\mathrm{t}}}\left\{\left(\mathrm{t}(\mathrm{x})-\mathrm{t}_{0}(\mathrm{x})\right)(\mathrm{f}(\mathrm{x})-\mathrm{t}(\mathrm{x}))\right\}<0 \quad \forall \mathrm{t} \in \mathrm{T}-\left\{\mathrm{t}_{0}\right\}$
(c) $\max _{\mathrm{t} \in \mathrm{T}-\left\{\mathrm{t}_{0}\right\}}\left\{\left(\mathrm{t}(\mathrm{x})-\mathrm{t}_{0}(\mathrm{x})\right)(\mathrm{f}(\mathrm{x})-\mathrm{t}(\mathrm{x}))\right\}<\max _{\mathrm{x} \in \mathrm{X}_{\mathrm{t}}}\left\{\left(\mathrm{t}_{0}(\mathrm{x})-\mathrm{t}(\mathrm{x})\right)\left(\mathrm{f}(\mathrm{x})-\mathrm{t}_{0}(\mathrm{x})\right)\right\}$

Proof: From proposition (1) it follows that (a) $\Rightarrow$ (b)

Since $(a) \Rightarrow(1)$, by proposition (2), (a) $\Rightarrow$ (b), thus (c) follows from (1) and (b)

Hence $(\mathrm{a}) \Rightarrow$ (c)

Suppose that, if possible, (b) $\Rightarrow$ (a) and (c) $\Rightarrow$ (a)

Let $\mathrm{t} \in \mathrm{T}-\left\{\mathrm{t}_{0}\right\}$ be an infinitesimal approximation of $\mathrm{f}$ in $\mathrm{T}$

Then by proposition (2),(5) holds, which contradicts (b), and by proposition (1), we have

$$
\max _{x \in X_{t}}\left\{\left(t_{0}(x)-t(x)\right)(f(x)-t(x))\right\} \leq 0
$$

Which is together with (5) contradicts (c). 


\section{REFERENCES}

[1] Diener, F. and Diener, M.; Nonstandard Analysis in practice, Springer-Velag, Berlin, Heidelberg, (1995).

[2] Keisler, H. J.; Elementary Calculus $2^{\text {ed }}$ An Infinitesimal Approach, Creative commons, 559 Nathan Albott, stanford, California, 93405,USA (2005).

[3] Nelson, E.; Internal se theory- A New Approach to nonstandard analysis, Bull. Amer. Math. Soc. Vol. 83, No. 6 (1977) pp.11651198.

[4] Robinson, A.; Nonstandard Analysis $2^{\text {ed }}$, North-Holland, pub. Comp. (1974).

[5] Rosinger, E. E.; Short introduction to Nonstandard Analysis, ar Xiv; math. C-M/0407178 VIIO Jul (2004).

[6] Stroyan, K. D. and Luxemburg W. A.; Introduction to the theory of infinitesimals, New York, Academic Press (1976). 